\title{
COMPARATIVE LITERATURE: AN OVERVIEW
}

\section{Rohib Adrianto Sangia}

\begin{abstract}
Comparative literature is an academic field dealing with the literature of two or more different linguistic, cultural or nation groups (D'haen, Domínguez, \& Thomsen, 2012: 57). While most frequently practiced with works of different languages, comparative literature may also be performed on works of the same language if the works originate from different nations or cultures among which that language is spoken. Also included in the range of inquiry are comparisons of different types of art; for example, a relationship of film to literature.
\end{abstract}

Keywords: Comparative Literature, World Literature, Literature Works

\section{INTRODUCTION}

The terms "Comparative Literature" and "World Literature" are often used to designate a similar course of study and scholarship (Enani, 2005: 27). Comparative Literature is the more widely used term in the United States, with many universities having Comparative Literature departments or Comparative Literature programs.

Comparative literature is an interdisciplinary field whose practitioners study literature across national borders, across time periods, across languages, across genres, across boundaries between literature and the other arts (music, painting, dance, film, etc.), across disciplines (literature and psychology, philosophy, science, history, architecture, sociology, politics, etc.) (Tötösy de Zepetnek, 1998: 80) (Cao, 2013: xix). Defined most broadly, comparative literature is the study of "literature without borders" (Dominguez, Saussy, \& Villanueva, 2014: xv). Scholarship in Comparative Literature include, for example, studying literacy and social status in the Americas, studying medieval epic and romance, studying the links of literature to folklore and mythology, studying colonial and postcolonial writings in different parts of the world, asking fundamental questions about definitions of literature itself.

What scholars in Comparative Literature share is a desire to study literature beyond national boundaries and an interest in languages so that they can read foreign texts in their original form (College Entrance Examination Board, 1992: 249). Many comparatists also share the desire to integrate literary experience with other cultural phenomena such as historical change, philosophical concepts, and social movements.

This paper eventually is going to involve in comparative assignment according to the option from the lecture. From all possible five options, this midterm paper assignment will be occupied by two questions that should be solved. The first assignment is purposed to expose with depth essay based on subchapter entitle Russia in French Letters: Milestones of a Discovery in Jost (1974: 62). For the second assignment, this paper will include the 
comparative analysis between Dostoevsky (2005) Notes from the Underground and Coetzee (1999) Disgrace that should be concern with applying American school analysis.

\section{RUSSIA IN FRENCH LETTERS}

In this part, there will be divided into two parts, they are the Russian literature history and the influence of French to Russian.

\section{Russian Literature History at Glance.}

At the beginning of the 19th century much of Western Europe viewed Russia as hopelessly backward--even medieval. It was considered more a part of Asia than an outpost of European thought (Cassedy, 2005: 51). During the first half of the century, indeed, peasants (called "serfs") were still treated as the property of their feudal masters and could be bought and sold, though they had a few more rights than slaves. Russian serfs gained their freedom only in 1861, two years before the American Emancipation Proclamation (Morton, 1967: 338).

However, the nobility of Russia had looked to the West for ideals and fashions since the early $18^{\text {th }}$ Century, when Peter the Great had instituted a series of reforms aimed at modernizing the country. Russian aristocrats traveled extensively in Western Europe and adopted French as the language of polite discourse. They read French and English literature and philosophy, followed Western fashions, and generally considered themselves a part of modern Europe (Moore \& Krystoforski, 2011: 155). St. Petersburg was created the new capital of Russia in 1721, and remained the most Westernized of Russian cities. Indeed, Dostoyevsky was to consider it an alien presence in the land, spiritually vacuous compared to the Old Russian capital of Moscow.

The German-born czarina Catherine the Great, who reigned from 1762 to 1796 , corresponded with Voltaire and fancied herself an Enlightenment monarch; but her plans for liberal reforms came to nothing, and she became better known as vainglorious autocrat (Gorbatov, 2006: 94). Despite the general backwardness of Russian society, its openness to the West (briefly interrupted by Napoleon's 1812 invasion) had profound influences on its literature throughout the 19th Century. The first great national author of Russia, Alexander Pushkin (1799-1837)--despite his celebration of Russian history and folklore--was profoundly influenced by such English writers as Shakespeare, Byron and Scott. Although he plays a role in Russian literature comparable to that of Goethe in Germany or even Shakespeare in England, his works were little known abroad during his lifetime. 
It was Ivan Turgenev (1818-1883)--who lived and wrote for many years in Europe and was profoundly Western in his outlook--that first brought Russian literature to the attention of European readers, but at the cost of often being considered an alien in his own land. It was the twin giants Leo Tolstoy and Fyodor Dostoyevsky whose work exploded out of Russia in the 1870 s to overwhelm Europeans with their imaginative and emotional power. To many readers it must have seemed as if this distant, obscure country had suddenly leaped to the forefront of contemporary letters. Both were profoundly influenced both by European Romanticism and Realism, but their fiction offered characters more complex and impassioned than those Europeans were used to.

Tolstoy is known chiefly for his two masterpieces, War and Peace (1865-1869) and Anna Karenina (1875-1877). These works which wrestle with life's most profound questions earned Tolstoy the reputation of perhaps the world's greatest novelist. The first is a vast portrait of Russia during the period of the Napoleonic wars, and the second the story of a tormented adulterous woman treated far more seriously than Flaubert's Emma Bovary. Like the English Victorian novelists, Tolstoy sought to do more than entertain or even move his readers, taking the writing of fiction seriously as a moral enterprise. In the end Tolstoy became a Christian utopian, abandoning fiction altogether.

Dostoyevsky is famous for his complex analyses of the human mind. Unlike Turgenev or Tolstoy, he pays little attention to details of setting or the personal appearance of his characters, instead concentrating on their thoughts and emotions (Jost, 1974: 75). His work and that of Tolstoy revealed to Europeans that modern fiction could serve ends far more sophisticated than it had in the hands of Zola or even Flaubert.

Dostoyevsky had a sensational life which is variously reflected in his fiction. He believed his father to have been murdered by his own serfs, a belief which led him to be obsessed with murder as a subject in many of his greatest works, such as Crime and Punishment (1866) and The Brothers Karamazov (1881). After being arrested for his involvement in a radical group (the model for The Possessed) he was abruptly notified that he was about to be shot, but was spared at the last minute and sent to Siberia for ten years. He often described the traumatic effect which this mock-execution had on him in his fiction, and devoted another novel (The House of the Dead) to the story of his time in prison.

While there, he developed epilepsy, and later made epileptic seizures one of the chief characteristics of the Christ-figure Prince Myshkin in The Idiot. He also analyzed his addiction to gambling in The Gambler. The fervent Christianity and anti-Western, anti-Enlightenment attitudes of his later years color much of his writing, and underlie the influential long story Notes from Underground. 
Some Western readers, notably the very restrained American novelist Henry James, found Dostoyevsky's fiction exaggerated. The combination of traditional Russian effusiveness with Dostoyevsky's truly sensational life made for sensational writing (Stam, 2004: 124). But it is important to note that though his characters always seem to be undergoing some sort of torment, he creates the extreme situations and emotions in his novels not out of mere sensationalism, but to plumb the depths of human experience.

Of the other Russian writers of the 19th Century, the only other one to make much of an impression abroad was Anton Chekhov (1860-1904), whose short stories and plays used Realism in a much more understated way. His four great plays written just before and after the turn of the century-- The Sea Gull, Uncle Vanya, Three Sisters, and The Cherry Orchard, along with the Realist masterworks of the Norwegian Henrik Ibsen--helped to rescue the theater from the dismal state into which it had plunged after the time of the German Romantics. The theatrical genius of the 19th century seems to have gone into opera rather than stage plays; few of the plays written between Schiller and Chekhov are remembered or performed today, but his works are seldom absent from the stage for long.

Chekhov's works are often seen as the last echo of a fading tradition before Stalinism made "socialist realism" into a suffocating orthodoxy. Under Communism, Tolstoy was regarded a great national writer despite his mystical leanings because of his sympathies with the peasants and utopian idealism; but Dostoyevsky was out of favor during much of the Stalinist period because he was an outspoken foe of socialism and fervent Christian. Yet abroad, his reputation continued to grow. He was seen as a prophet of the evils which followed in the wake of the Bolshevik Revolution, as a psychologist who anticipated many of the most striking discoveries of Sigmund Freud, and as a welcome challenger to the pervasive celebration of modernity so characteristic of the period 1850-1960. Despite his antimodernism, Dostoyevsky still speaks directly to many readers in ways that most of his contemporaries do not. In post-Communist Russia he is again celebrated as a national treasure, just as he is revered as a classic abroad.

\section{THE INFLUENCE OF FRENCH TO RUSSIAN}

The first real manifestations of the influence of France in Russia date from Russia's first political opening toward Europe, undertaken by Peter the Great (1682-1725) and further advanced by Catherine II (1762-1796) (Smith, 2006: 18). In the first instance, this influence was cultural. The adoption of the French language as the language of conversation and correspondence by the nobility encouraged access to French literature. The nobility's preference for French governesses and tutors contributed to the spread of French culture and 
educational methods among the aristocracy. At the beginning of the nineteenth century, the Russian nobility still preferred French to Russian for everyday use, and were familiar with French authors such as Jean de la Fontaine, George Sand, Eugene Sue, Victor Hugo, and Honoré de Balzac.

The influence of France was equally strong in the area of social and political ideas. Catherine II's interest in the writings of the philosophers of the Enlightenment-Baron Montesquieu, Jean Le Rond d'Alembert, Voltaire, and Denis Diderot-contributed to the spread of their ideas in Russia during the eighteenth century (Gorbatov, 2006: 94). The empress conducted regular correspondence with Voltaire, and received Diderot at her court. Convinced that it was her duty to civilize Russia, she encouraged the growth of a critical outlook and, as an extension of this, of thought regarding Russian society and a repudiation of serfdom, which had consequences following her own reign.

The support of Catherine II for the spirit of the Enlightenment was nonetheless shaken by the French Revolution of 1789 (Gorbatov, 2006: 227). It ceased entirely with the execution of King Louis XVI (January 1793). The empress was unable to accept such a radical challenge to the very foundations of autocratic rule. From the close of her reign onward, restrictions on foreign travel increased, and contacts were severely curtailed. Despite this change, however, liberal ideas that had spread during the eighteenth century continued to circulate throughout Russia during the nineteenth, and the French Revolution continued to have a persistent influence on the political ideas of Russians. When travel resumed under Alexander I (ruled 1801-1825), Russians once again began to travel abroad for pleasure or study. This stimulated liberal ideas that pervaded progressive and radical political thought in Russia during the nineteenth century. The welcome that France extended to political exiles strengthened its image as a land of liberty and of revolution.

During the nineteenth century, travel in France was considered a form of cultural and intellectual apprenticeship (Jost, 1974:75). Study travel abroad by Russians, as well as trips to Russia by the French, shared a common cultural space, encouraging exchanges most notably in the areas of fine arts, sciences, and teaching. Because they shared geopolitical interests vis à vis Germany and Austria-Hungary, France and Russia were drawn together diplomatically and economically after 1887. This resulted, in December 1893, in the ratification of a defensive alliance, the French-Russian military pact. At the same time, French investment capital helped finance the modernization of the Russian economy. Between 1890 and 1914 , numerous French industrial and banking houses established themselves in Russia. French and Belgian capital supplied the larger part of the flow of investment funds, the largest share of which went into mining, metallurgy, chemicals, and especially railroads. The largest French 
banks, notably the Crédit Lyonnais, made loans to or invested in Russian companies. Public borrowing by the Russian state, totaling between eleven and twelve billion gold francs, was six times greater than direct investment on the part of the French.

On the eve of 1914, there were twelve thousand French nationals in Russia. Forty consuls were in the country looking out for French interests. French newspapers had permanent correspondents in St. Petersburg. In 1911, l'Institut Français (a French institute) was created there to help spread French culture in Russia. In fact, from the 1890s onward, France's cultural presence in Russia was consistently viewed as an adjunct to its policy of industrial and commercial implantation.

Following the close of the nineteenth century, the role of France as a land that welcomed political exiles and refugees had a reciprocal influence on the countries from which they came. When they returned to Russia, some of these individuals brought back ideas as well as social, pedagogical, and political experiences. For example, the experience acquired by Maxim Kovalevsky (1851-1916), professor of law and sociology, as the head of the Ecole supérieure russe des sciences sociales de Paris (the Russian Advanced School for Social Sciences in Paris), founded in 1901, served to organize the Université populaire Shanyavsky in Moscow (the Shanyavsky People's University), founded in 1908.

After the October Revolution of 1917, Paris, along with Berlin and Prague, was one of the three principal cities of Russian emigration in Europe. A hub of intellectual activity from the 1920s onward, the French capital was among the leading centers abroad for publishing Russian newspapers and books, of which a portion subsequently made its way into Russia, thereby helping to bind the emigrant population with Soviet Russians back home. The suspension of scientific and cultural relations between the USSR and the rest of the world, starting in the mid-1930s, put an end to this exchange.

The cultural influence of France did not disappear, however. Beginning in 1954, new attempts were made to bring France and the USSR closer together, beginning with cultural exchanges. During that year the Comédie française made a triumphant tour of the Soviet Union (Zaretsky, 2010: 113). Later, the trip by General Charles de Gaulle, in June of 1966, marked the beginning of a time of privileged relations between the two countries. A joint commission was created to foster exchange, and numerous cultural agreements were signed, some of which remained in effect during the early twenty-first century. French teaching assistants were appointed in Soviet universities, the teaching of French was expanded at the secondary school level, and agreements were signed for the distribution of French films in the USSR. 
The perception of the Russian people, France has remained the country of the Revolution of 1789 and the homeland of the Rights of Man (Marinova, 2011: 114). From the 1960s onward, French intellectuals outside of Russia strengthened this image by supporting the cause of Soviet dissidents. It is again in the name of human rights that France has attempted, since 1994, to soften the position of the Russian government with regard to Chechnya.

\section{COMPARATIVE ANALYSIS}

In this part of there will be consisted with three sub-parts. The first is the theoretical review about comparative literature and American school method in comparing literatures. The second part would be the section which deliberate the literature that will be compare in synopsis and author backgrounds. The three, last but not least, is the part where the comparative method is being applied in analyzing both of the works. As consideration, both works is well-known come from Russia and South Africa.

\section{Theoretical Review of American School}

Comparative literature has been a subject of concerns, for the primary excitement, after its proposition by Johann Wolfgang von Goethe, Abel Francois Villemain, and Matthew Arnold by the mid-1850s after its brief history of six decades, was replaced by questioning of the various terminology, nature and functions of Comparative Literature (Paranjape, 2015: $15)$.

By considering development of Comparative Literature in terms of its Schools, it is possible not only to comprehend its past but also to anticipate its future on the basis of the developments in the past. The French school focused on influence or reception with its basis on positivism (Jost, 1974: 74). The British School studied in 'placing' in which 'placing' of texts leads to shared enlightenment of scripts. The American School of comparative literature questioned the dominance of the French school and its principal practice in the post-World War II period with focus on interdisciplinary approach. It opened the scope of comparative literature through Henry Remak and Rene Wellek.

Henry Remak founded the American school of comparative literature and also of its distinction from the French school. While the French school concerned itself with 'product', the American School emphasized on the 'process' of the 'product' coming into existence (Wehn, 1997: 361). Moreover, it opened up the frontiers of Comparative Literature and transgressed boundaries of the discipline. 
American scholars of Comparative Literature believed that the study of similarity was introduced by the schools, but actually it was reestablished by the American school. Moreover, Cao (2013: xxiii) deliberated into three parts. The first is the negation of the French school to analogy studies since the French school excluded analogy studies. The second is the reason why the American school emphasizes the transnational and interdisciplinary nature of Comparative Literature that comparing the products of different national literatures, comparing between literatures and other subjects, and sorting out the common aesthetic values and the universal laws in literature and literary development. Finally, the focus of the American school is the study of thematology, typology, stylistics, and so on. Among them, thematology is the study of writers of different countries and their different treatment on the same subject, which includes the research on motif, situation, and image.

The American School promotes largely two theories, namely, 'Parallelism' and 'Intertextuality'. The theory of 'Parallelism' is derived from the idea of similarities in humanity's social and historical evolution, that is, harmony in the process of literary development (Enani, 2005: 41; Tötösy de Zepetnek, 1998: 16).

Many comparatists in America and Eastern Europe had adopted The 'Parallel' theory. According to Konrad, a Russian comparatist sees that this theory is derived from the idea of similarities in humanity's social and historical evolution, which means harmony in the process of literary development. There are similarities between the literatures of different peoples whose social evolution is analogous, irrespective of existence of mutual influence or direct relation between them found in study of parallelism (Short, 1986: 156). In advance, the comparatist seeks to define the origins and evidences which emphasize collective structures between works and authors, or the association of a occurrence with a particular form. this theory account that literatures are unlike rendering to their determining national and historical backgrounds, it is important in the common properties of literary phenomena to related with the national and historical attributes of each phenomenon.

Parallelism theory does not give importance to the link of causality and no importance to influence. There is a possibility of dealing with literary texts not being in contact of whatsoever kind but having similar contexts or realities. If influence exists between literary texts, the importance does not lie in the influence itself but rather in the context. If the context does not allow for influence to be effective, influence will never take place in the first place.

This term "intertextuality" was established by the poststructuralist Julia Kristeva in the 1960s, and since then it's been widely accepted by postmodern literary critics and theoreticians (Allen, 2000: 3). The study of this terminology was a response to Ferdinand de 
Saussure's theory and his claim that signs gain their meaning through structure in a particular text. It has been argued that readers are always influenced by other texts, sifting through their archives, when reading a new one.

The corporatist has several technical terms to describe intertextual relationship between two texts. If it is a source and product relationship, it can be termed imitation, influence, adaptation, parody or subversion. The history and literature of a country, in the current social and political scenario, remains incomplete if the country's aboriginal heritage and culture get ignored in its waiting. Comparative literature shows the relationship between the two texts or two authors.

Intertextuality means the reference of a given text to another text. New texts are superposed on old texts. New texts (Hypertexts) are always read under the light of old texts (Hypotexts). Literature is a continuous and an ongoing process of reworking and refashioning old text. Old texts turn into some sort of raw materials used for the creation of new ones.

\section{About the works}

Fyodor Mikhailovich Dostoevsky was born October 30, 1821, in Moscow's Hospital for the Poor. He was the second of seven children born to a former army surgeon, who was murdered in 1839 when his own serfs poured vodka down his throat until he died. Following a boarding school education in Moscow with his older brother Mikhail, Fyodor was admitted to the Academy of Military Engineers in St. Petersburg in 1838. He completed his studies in 1843, graduating as a lieutenant, but was quickly convinced that he preferred a career in writing to being mired in the bureaucratic Russian military. In 1844 he published a translation of Balzac's Eugenie Grandet, and he followed these two years later with his first original published work, Poor Folk, a widely-acclaimed short novel championed by the influential critic Vissarion Belinsky.On April 23, 1849, Dostoevsky was arrested with other members of the Petrashevsky circle and was sentenced to death to work as materialist atheism. He was placed in solitary confinement in the Petropavlovsky Fortress for eight months. During this time, Tsar Nikolai I changed his sentence but ordered that this change only be announced at the last minute. On December 22, Dostoevsky and his fellow prisoners were led through all the initial steps of execution, and several of them were already tied to posts awaiting their deaths when the reprieve was sounded.

In 1862 Dostoevsky went abroad. He visited France, Germany, Switzerland, Italy, and England. In London he attended the 1862 World's Fair and had a first-hand look at the Crystal Palace, the architectural wonder of the age. The image of the Crystal Palace, which for progressive critics symbolized the dawning of a new age of reason and harmony, was to loom 
large in Dostoevsky's works to come, especially Notes from Underground and Crime and Punishment. In 1863, leaving his ailing wife behind, he made a second trip to Europe. (Marya Isaeva, Dostoevsky's first wife, died in 1864.)

Notes from Underground was first published in January and February of 1864 as the featured presentation in the first two issues of The Epoch, Dostoevsky's second journal of the 1860s. The novel was written at one of the lowest points of Dostoevsky's career.

The novel begin with The narrator introduces himself as a man who lives underground and refers to himself as a spiteful person whose every act is dictated by his spitefulness. Then he suddenly admits that he is not really spiteful, because he finds it is impossible to be anything - he can't be spiteful or heroic; he can only be nothing. This is because he is a man of acute consciousness and such a person is automatically rendered inactive because he considers too many consequences of any act before he performs the act and therefore never gets around to doing anything. In contrast, a person who is not very intelligent can constantly perform all sorts of actions because he never bothers to consider the consequences.

The man of acute consciousness finds that he cannot even commit an act of revenge because he never knows the exact nature of the insult. Such a man is plagued with an active imagination which causes him to exaggerate any type of insult until it becomes fantasized out of all proportion to the original insult. By this time it is ridiculous to try and perform any act of revenge.

It is easy for other people to classify themselves, but the Underground Man knows that no simple classification can define the essence of one's existence; therefore, he can only conclude that he is nothing. Yet in society, the scientists and the materialists are trying to define exactly what a man is in order to create a society which will function for man's best advantage. The Underground Man objects to this trend because he maintains that no one can actually know what man's best advantage is. Such a society would have to be formulated on the theory that man is a rational being who always acts for his best advantage. But the history of man proves that he seldom acts this way.

The Underground Man then points out that some people love things which are not to their best advantage. Many people, for example, need to suffer and are ennobled by suffering; yet, the scientist and the rationalist want to remove suffering from their utopian society, thereby removing something that man passionately desires. What the Underground Man wants is not scientific certainty, but the freedom to choose his own way of life.

The Underground Man concludes that for the man of conscious intelligence, the best thing to do is to do nothing. His justification for writing these Notes from Underground is that 
every man has some memory which he wishes to purge from his being, and the Underground Man is going to tell his most oppressing memory.

Sixteen years ago, when he was twenty-four, he lived a very isolated and gloomy existence with no friends and no contacts other than his colleagues at work. To escape the boredom of this life, he turned to a life of imagination. There he could create scenes in which he had been insulted and then could create ways of revenging himself. But he never fulfilled his dreams.

When his isolation became too unbearable, he would visit his immediate superior at his home. Once, however, feeling the need to "embrace humanity," he was driven to renew his acquaintance with an old schoolmate, Simonov. Arriving at the house, he found Simonov with two old schoolmates discussing a farewell party they were planning for Zverkov. The Underground Man invited himself to the party even though he had always hated Zverkov and had not seen him since their school days.

At the party, the Underground Man unknowingly arrived an hour early (the time had been changed) and, during the course of the evening, created a repulsive scene. When the others left to go to a brothel, he begged for some money from Simonov so that he could go too. He was ashamed and horrified at what he had done, but he followed his companions to the brothel.

When he arrived, he was determined to slap Zverkov, but he could not find him; he was relieved to discover that everyone had already retired. Then he met Liza, a prostitute with whom he retired. Later, he awakened and told her in high-flown language about the miseries of prostitution. He knew he was doing so partly for effect and partly because he felt rejected by his friends. Upon leaving, he gave Liza his address and told her to visit him. She promised to do so.

During the next day and for days afterward, the Underground Man was horrified that Liza might actually show up. He knew that he could not keep up the pretense of the previous night. And, one night as he was having an absurd argument with his servant, she did arrive. He was embarrassed that she should see him in such poverty and in such an absurd position. He went into hysterics, and she comforted him. Later, he insulted her and told her that he was only pretending about everything he said. Crudely, he gave her five rubles for her services, but before she left, she crumpled the five-ruble note and left it on his table. He ran after her to apologize but could not find her. In the end, His shame over his conduct still troubles him.

The second novel author, Coetzee was born in Cape Town on 9 February 1940 , and grew up in the Karoo, the vast desert and semi-desert area of the Cape province. His family (his father was a lawyer; his mother a schoolteacher) spoke English at 
home, though, with other relatives, he conversed in Afrikaans. He completed his undergraduate work, studying English and mathematics at the University of Cape Town, in 1961, and moved to England to work in computers in 1962. He stayed for four years, working as a programmer, during which period he wrote a master's thesis on Ford Madox Ford.

In 1965, Coetzee returned to academia: he moved to the US, to the University of Texas at Austin, where he produced his doctoral dissertation on the style of Samuel Beckett's English fiction, completed in 1969. He taught at the State University of New York at Buffalo from 1968 to 1971 . He returned to South Africa to take up a teaching position at the University of Cape Town in 1972. Following successive promotions, he became professor of general literature at his Alma Mater in 1984.

Set in post-apartheid South Africa, the novel tells the story of David Lurie, a twice divorced, 52-year-old professor of communications and Romantic Poetry at Cape Technical University. Lurie believes he has created a comfortable, if somewhat passionless, life for himself. He lives within his financial and emotional means. Though his position at the university has been reduced, he teaches his classes dutifully; and while age has diminished his attractiveness, weekly visits to a prostitute satisfy his sexual needs. He considers himself happy. But when Lurie seduces one of his students, he sets in motion a chain of events that will shatter his complacency and leave him utterly disgraced.

Lurie pursues his relationship with the young Melanie-whom he describes as having hips "as slim as a twelve-year-old's"-obsessively and narcissistically, ignoring, on one occasion, her wish not to have sex. When Melanie and her father lodge a complaint against him, Lurie is brought before an academic committee where he admits he is guilty of all the charges but refuses to express any repentance for his acts. In the furor of the scandal, jeered at by students, threatened by Melanie's boyfriend, ridiculed by his ex-wife, Lurie is forced to resign and flees Cape Town for his daughter Lucy's smallholding in the country. There he struggles to rekindle his relationship with Lucy and to understand the changing relations of blacks and whites in the new South Africa. But when three black strangers appear at their house asking to make a phone call, a harrowing afternoon of violence follows which leaves both of them badly shaken and further estranged from one another. After a brief return to Cape Town, where Lurie discovers his home has also been vandalized, he decides to stay on with his daughter, who is pregnant with the child of one of her attackers. Now thoroughly humiliated, Lurie devotes himself to volunteering at the animal clinic, where he helps put down diseased and unwanted dogs. It is here, Coetzee seems to suggest, that Lurie gains a redeeming sense of compassion absent from his life up to this point. 
3. The application of American School into novels

By looking at theme, at least there are two similar themes that we can found in both novels. They are suffering and hate. Hate is a theme that runs, sometimes bubbling quietly under the surface, and other times bursting forth with full force. In Disgrace, it is not unusual for characters to either feel or outright demonstrate hatred towards others. In some instances, it is restrained - think of the scene in which Mr. Isaacs accosts David at the University, when David secretly wants to throttle Petrus, or when David regards the women of the committee hearing with secret dislike. In other moments, it is overt, like when David tries to beat the stuffing out of Pollux. Hate, however, isn't just something that characters feel toward others; sometimes characters who don't obviously demonstrate feelings of hate feel hated. Lucy is a prime example; she reports feeling hate radiating toward her from the men who rape her, but she doesn't talk about feeling the same way towards them.

"I am a sick man... I am a spiteful man. I am an unattractive man." These are the opening words of Notes from the Underground, and indeed the Underground Man lives in a constant state of misdirected and paralyzing spite. His plight, he explains, is worsened by the fact that an intelligent man of consciousness cannot alleviate his spite through revenge; he is so conscious and so intelligent that he raises doubt after doubt until he is paralyzed in inaction. So instead, the Underground Man harbors his spite underground - even for the most trivial offenses - for decades.

Everyone suffers in some way in Disgrace, and suffering takes place in a number of forms. Multiple examples of physical suffering pop up through the book: the goat with the infected scrotum at the animal clinic bleats in pain (we know, ew); David withstands being knocked out and set on fire; the dogs in the kennel are viciously executed, except for one that just lies there bleeding to death and waiting to die. These are all disturbing examples of physical suffering, but it's also important to think about the role that emotional and mental suffering plays in the novel; it seems that nobody escapes without some serious psychological wounds. While we don't witness Lucy's rape firsthand, we see how it changes her into a mere shadow of her former self who patters around the house and refuses to see people. David's own worries about Lucy constitute a major source of suffering for him. These, of course, are just a couple of examples of how suffering afflicts the mind as much as it does the body.

In Notes from the Underground, the Underground man argues that suffering is enjoyable - even a toothache. The pleasure, he says, comes when you are intensely conscious of your pain, adding that it's enjoyable to make others suffer with you. Suffering is necessary, 
he continues, because it leads to consciousness. The two notions - suffering and consciousness - have a complicated relationship in the text, each necessitating the other and making the other possible. For this reason, man will never give up suffering, since man needs to be conscious and have his free will. He will even purposely cause himself pain to prove that he's free to do so.

Like many of J.M. Coetzee's novels, Disgrace takes place in his native South Africa, a country that for many years was ruled under a system of racial segregation called Apartheid. Apartheid, which in Afrikaans means "separateness," was a system held in place from 1948 until 1994. It was official policy under which the rights of blacks were severely limited and under which whites, though the minority in terms of numbers, were in charge. Under Apartheid, blacks were not even considered to be legal citizens of South Africa, and they were forced to attend separate schools, go to separate hospitals, and receive separate public services. When blacks were deprived of their citizenship, they were divided into self-governing tribes called Bantustans.

Disgrace takes place only several years after the end of Apartheid, and as a result, knowing a little bit about the geography and systems of Apartheid are really helpful in understanding the undertones of this book. The novel begins in the far Western reaches of South Africa in Cape Town, where David is a professor at the University. Cape Town was generally considered to be part of "white" South Africa during Apartheid. In Disgrace, we see it as being more developed and cosmopolitan. When David leaves to go to live with Lucy in Salem, he's headed to a completely different part of the country: the Eastern Cape, which was long considered to be part of "black" South Africa and where the Bantustans were established.

It is similar with the social setting of Notes from the Underground where that times that Russia in the transition in being civilized by adopting the European culture. That was Dostoevsky's time/place context for writing this work, but it's also the time and place in which the Underground Man is set. Notes from Underground is set in the city of St. Petersburg (now Leningrad) in nineteenth-century Russia. Unlike other cities of Europe, it has no long history since it was only established at the beginning of the eighteenth century by Peter the Great. Built to be the seat of government, St. Petersburg was designed as an impressive city. It was laid out with symmetrical streets, and Italian and French architects produced magnificent palaces to be built there. By the nineteenth century, the time of the novel, St. Petersburg had become a bustling city on the Gulf of Finland. Turgenev, Chernyshevsky, the Crystal Palace, rational egoism, socialism, the fall of the feudal system - these all compose the setting for Notes and the intellectual environment to which the Underground Man is responding. 


\section{REFERENCES}

Allen, Graham. (2000). Intertextuality. New York: Routledge.

Cao, Shunqing. (2013). The Variation Theory of Comparative Literature. London: Springer.

Cassedy, Steven. (2005). Dostoevsky's religion. Stanford: Stanford University Press.

Coetzee, J. M. (1999). Disgrace (1st American ed.). New York: Vikings.

College Entrance Examination Board. (1992). Guide to 150 popular college majors. New York: The Board: Distributed to the trade by Macmillan.

D'haen, Theo, Domínguez, César, \& Thomsen, Mads Rosendahl. (2012). World Literature : A Reader. London: Routledge.

Domínguez, César, Saussy, Haun, \& Villanueva, Darío. (2014). Introducing Comparative Literature : New Trends and Applications. New York: Routledge.

Dostoevsky, Fyodor. (2005). Notes From the Underground. Planet PDF.

Enani, M. M. (2005). Theories of Comparative Literature. Cairo.

Gorbatov, Inna. (2006). Catherine the Great and the French Philosophers of the Enlightenment: Montesquieu, Voltaire, Rousseau, Diderot and Grimm. Bethesda: Academica Press.

Jost, Franc,ois. (1974). Introduction to Comparative Literature. Indianapolis: Pegasus.

Marinova, Margarita. (2011). Transnational Russian-American travel writing. New York: Routledge.

Moore, Christopher, \& Krystoforski, Andrej. (2011). From Then to Now : A Short History of The World Toronto: Tundra Books.

Morton, Miriam. (1967). A Harvest of Russian Children's Literature. Berkeley: University of California Press.

Paranjape, Makarand R. (2015). Tagore's Idea of "World Literature". In D. Banerji (Ed.), Rabindranath Tagore in the 21st Century (pp. 53-67). New Delhi: Springer.

Short, Michael H. (1986). Literature and Language Teaching and The Nature of Language. In T. D. Haen (Ed.), Linguistics and the Study of Literature. Amsterdam: Rodopi.

Smith, May. (2006). The Influence of French on Eighteenth-Century Literary Russian : Semantic and Phraseological Calques. Oxford: Peter Lang. 
Stam, Robert. (2004). Literature Through Film : Realism, Magic, and the Art of Adaptation. Malden: Blackwell Pub.

Tötösy de Zepetnek, Steven. (1998). Comparative Literature: Theory, Method, Application. Amsterdam: Rodopi.

Wehn, Karin. (1997). Canon Formation in Television Studies. In S. T. de Zepetnek \& I. Sywenky (Eds.), The Systemic and Empirical Approach to Literature and Culture as Theory and Application. Edmonton: University of Alberta.

Zaretsky, Robert. (2010). Albert Camus, elements of a life. Ithaca: Cornell University Press. 